\title{
Three Different Ways to Skin a Cat Financialization in the Emergence of National e-ID Solutions
}

\author{
Eaton, Ben; Hedman, Jonas; Medaglia, Rony
}

Document Version

Accepted author manuscript

Published in:

Journal of Information Technology

DOI:

$10.1057 / s 41265-017-0036-8$

Publication date:

2018

License

Unspecified

Citation for published version (APA):

Eaton, B., Hedman, J., \& Medaglia, R. (2018). Three Different Ways to Skin a Cat: Financialization in the Emergence of National e-ID Solutions. Journal of Information Technology, 33(1), 70-83.

https://doi.org/10.1057/s41265-017-0036-8

Link to publication in CBS Research Portal

\section{General rights}

Copyright and moral rights for the publications made accessible in the public portal are retained by the authors and/or other copyright owners and it is a condition of accessing publications that users recognise and abide by the legal requirements associated with these rights.

Take down policy

If you believe that this document breaches copyright please contact us (research.lib@cbs.dk) providing details, and we will remove access to the work immediately and investigate your claim. 


\title{
Three Different Ways to Skin a Cat: Financialization in the Emergence of National e-ID Solutions
}

\section{Ben Eaton, Jonas Hedman, and Rony Medaglia}

\author{
Journal article (Accepted manuscript)
}

CITE: Eaton, B., Hedman, J., \& Medaglia, R. (2018). Three Different Ways to Skin a Cat: Financialization in the Emergence of National e-ID Solutions. Journal of Information Technology, 331), 70-83. 001: 10.1057/s41265017-0036-8

Copyright ( ¿ २०17. Association for Information Technology Trust. Reprinted by permission of SAGE Publications.

DOl: https://doi.org/10.1057/s41265-017-0036-8

Uploaded to CBS Research Portal: January २०19 


\title{
Three different ways to skin a cat: Financialization in the emergence of national e-ID solutions
}

\author{
Ben Eaton \\ Surrey Business School \\ Department of the Digital Economy \\ University of Surrey, Guildford GU2 7XH, \\ United Kingdom. \\ +447908 521219; b.d.eaton@surrey.ac.uk \\ Jonas Hedman \\ Copenhagen Business School \\ Department of IT Management \\ Howitzvej 60, 2000 Frederiksberg, Denmark \\ jh.itm@cbs.dk \\ Rony Medaglia \\ Copenhagen Business School \\ Department of IT Management \\ Howitzvej 60, 2000 Frederiksberg, Denmark \\ rm.itm@cbs.dk
}

Abstract

The growing phenomenon of financialization influences an array of societal dimensions that go beyond the economic realm, to include public policy making and information technology (IT). This study presents a cross-country analysis of the emergence of national electronic identification (e-ID) solutions as the result of interaction between the financial and the public sector in Denmark, Norway, and Sweden. Drawing on on-line sources, documents, and interviews from key actors in the three cases, we adopt a cross-disciplinary perspective by applying the lens of collective action theory to identify the role of interests, resources, and governance in the emergence of national e-ID solutions. Findings show that different governance solutions can emerge as the result of the convergence of interests and of interdependency of resources between the actors over time. We contribute to research on financialization and IT by proposing a dialectic process model and identifying five mechanisms that drive the process forward.

Keywords: Financialization, e-ID, collective action, cross-country comparison, case study 


\section{INTRODUCTION}

The phenomenon of financialization has received increasing attention in both public opinion and research in the past decades, especially following the global financial crisis of 2007-8. As the role of financial institutions acquires increasing relevance in a globalized world, economists, sociologists, and political scientists have come to describe financialization as "the increasing role of financial motives, financial markets, financial actors and financial institutions in the operation of the domestic and international economies" (Epstein, 2005: 3). Over time, and with the increased pervasiveness of financial actors, logics, and resources, financialization also has come to concern areas other than economic activities (Leyshon and Thrift, 2007). These would include areas traditionally within the competence of governments, such as public policy-making (Erturk and Solari, 2007; Hardie and Howarth, 2009; Leyshon and Thrift 2007), and the information technology (IT) sector. Nevertheless, research on financialization has so far focused mainly on the role of financial actors in transforming regimes of accumulation of wealth (Krippner, 2005) and in changing modes of management of the firm (Fligstein and Shin, 2004; Lin \& Tomaskovic-Devey 2013), even though financialization has implications beyond these research areas. For instance, we can see how financial actors and governments collaborate and compete.

One such interaction point is the establishment of electronic identification systems (Whitley and Hosein, 2008; Grönlund, 2010), used both by the financial sector and the public sector (Medaglia et al 2017). Official systems for the authentication of citizens, such as identification cards, have traditionally been the exclusive responsibility of state bureaucracies. However, the ongoing digital transformation has created a new type of identification, namely electronic identification (e-ID). From the government side, the need for developing e-IDs is spurred by the booming diffusion of citizen use of IT to access public services. However, the financial sector increasingly depends upon e-IDs to authenticate customers in accessing financial services. This provides opportunities and challenges for the public sector as well as the financial sector to collaborate.

The emergence of national e-ID solutions is thus a case in point to unpack the dynamics of the emerging relations between financial actors and governments in the development of shared IT. Such an emergent role represents a unique occasion to observe a largely underexplored instance of financialization at work, namely the one of IT in public policy making. Adopting the perspective of financialization, we expect the emergence of a shared IT, such as that enabling a public citizen authentication solution (e-ID), to be shaped by the dynamics of collaboration, negotiation, and conflict between financial and public actors. In this study, we set out to investigate this instance of financialization in the realm of public IT by addressing the following research question:

\section{How does the interaction between financial and public actors influence the emergence of national e-ID solutions?}

To answer this research question, we investigate the interplay between the financial sector and governments in the emergence of national e-ID solutions in three countries that have adopted this approach: Denmark, Norway, and Sweden. We unpack the transformation of interests, resources, and governance of relationships between banks and governments over time using the theoretical lens of collective action theory.

The paper is structured as follows. In the next section we discuss research on financialization and on e-ID solutions, and we present the theoretical framework of collective action. In the following section we motivate the choice of the cases, and present the methods used for collecting and analyzing the empirical data. We then outline the details of the emergence of national e-ID solutions in Denmark, Norway, and Sweden. In the findings section 
we illustrate how interests, resources, and governance of relationships between governments and the banking sector changed over time, distinguishing between three phases of transformation. We then propose a dialectic process model describing the emergence of national e-ID that extends on the collective action theory in Information Systems (IS). In the discussion section, we highlight contributions of the study to research and practice, the implications of our findings, and highlight limitations and future research. In the conclusion section we summarize the content of the study.

\section{BACKGROUND AND THEORETICAL FRAMEWORK}

\section{Financialization and public policy-making}

The concept of financialization has obtained a great deal of attention in scholarly research over the last decade. As a result, studies now cover a wide range of topics, including financialization of the economy, of management styles, and of public policy-making, from a variety of disciplines.

Originally, in economics research the term financialization has been used to describe the shift from industrial to financial capitalism, highlighting the emerging of finance beyond its traditional role of provider of capital for the productive economy. Financialization in this view refers to "a pattern of accumulation in which profit making occurs increasingly through financial channels rather than through trade and commodity production" (Krippner, 2005: 173). This view conceptualizes financialization as a new regime of accumulation of wealth or, more generally, as "transformation in which financial activities (rather than services more generally) have become increasingly dominant" (Krippner, 2011:2).

More recently, however, financialization has assumed a wider connotation, to include an array of phenomena of societal change, defined as a "web of interrelated processes economic, political, social, technological, cultural, etc. - through which finance has extended its influence beyond the marketplace and into other realms of life" (Zwan, 2014: 101). Within this trend, for instance, some studies talk about the financialization of the everyday (Zwan, 2014), to include a focus on impacts of the rise of financial actors, logics, and institutions on the values and behaviours of realms of society previously excluded from financial influence. This includes, on the one hand, at the individual level, the phenomenon of the "democratization of finance", with the inclusion of new parts of the population in the access to financial instruments (Erturk et al., 2007). On the other hand, at a policy-making level, it includes also a focus on a general shift towards financial markets for the provision of people's needs, including those traditionally tackled by state public services, through financial intermediaries such as banks (Erturk and Solari, 2007; Hardie and Howarth, 2009; Leyshon and Thrift, 2007). In this meaning, financialization does not just indicate a growth of financial flows but, more importantly, an increased convergence of finance and state service provision with, in particular, IT playing a central role (Davis, 2009). While such enriched view on financialization increases in relevance, there is still a dearth of empirical studies focusing on financialization in public policy-making and IT (Leyshon and Thrift, 2007).

Drawing on this latter, wider perspective, we refer to financialization in this study as the increased role of financial actors, such as banks, in the process of shaping public policymaking for the establishment of public IT. We thus conceptualize financialization within public-policy making as the result of the shifting relationships between state agents and financial actors engaged in interaction, conflict, and negotiation, and resulting in different modes of collective action, as is observable in the case of e-ID.

\section{Electronic ID research}


E-ID has been given some attention within research on e-government. Studies related to electronic identity focused on technological decision (Whitley and Hosein, 2008), trust and public value (Seltsikas and O'Keefe, 2010), surveillance (Lyon, 2009), security (Wihlborg, 2013), historical evolution (Hoff and Hoff, 2010), legal framework (Lentner and Parycek, 2016), innovation process (Kubicek and Noack, 2010), market governance (Grönlund, 2010), and life cycle (Melin et al., 2016). In this research a variety of theories, including innovation (Kubicek, 2010) and boundary object (Hedström et al., 2016) and methods, such as case studies (Hoff and Hoff, 2010) and surveys (Seltsikas and O'Keefe, 2010), have been applied.

Such array of studies, however, leaves a number of gaps in the focus they adopt. First, no study has adopted the perspective of financialization, even when analysing cases of e-ID that included the participation of financial actors (Hoff and Hoff, 2010; Melin et al., 2016). Second, while many studies provide accounts of e-ID solutions, very few of them focus on how they are shaped by the interactions between different classes of actors (Grönlund, 2010), even when adopting a comparative (Kubicek, 2010) or a longitudinal view (Hoff and Hoff, 2010; Kubicek and Noack, 2010).

\section{Theory of collective action}

We conceptualize the emergence of e-ID as a process of financialization which results from the interaction between public and financial actors in order to achieve the successful development and adoption of shared solutions. In doing so, governments and financial actors are able to overcome their differences and work together in order to generate a common e-ID for the use by citizens in applications ranging from access to e-government, to finance and commercial services requiring user identification and authentication.

The theory of collective action was first put forward by Olson (1965) and is a means of explaining the broad conditions under which actors are able to collaborate with each other in order to establish a common good. The key concern is how to manage and coordinate the governance of different groups of actors when they may have conflicting interests and different resources, as might be found in the context of governments cooperating with the financial industry. It has subsequently found widespread adoption in the social sciences (Ostrom, 2014; Rao et al., 2000). Collective action has found particular application in information systems studies, where the goal has been to understand how shared information infrastructures can emerge from amongst groups of diverse actors with differing interests and resources. The settings of these studies are varied, for example: amongst groups of banks and mobile operators attempting to establish a common mobile payments platform (de Reuver et al., 2015); in public healthcare providers and private research and development institutions establishing a regional health information infrastructure (Constantinides and Barrett, 2014); and in the emergence of industry-wide information system standardization in the residential mortgage industry (Markus et al., 2006). These perspectives and the sources that they draw upon inform our analysis. Studies of collective action directed at producing common IS goods are characterized by analysing the socio-technical arrangements around three key factors which need to be aligned in order that a common good can be successfully established: 1) the differing interests of the actors, 2) the varied resources of the actors, and 3) the governance of contributing actors (Markus et al., 2006; Constantinides and Barrett, 2014; de Reuver et al., 2015).

The various interests of the group of actors contributing to establish the collective IS good are a primary concern. These interests may be both economic, such as deriving commercial profit, and non-economic, such as gaining knowledge (Nikayin, 2014). Heterogeneous interests can bring conflicts of interest amongst different members, which can become problematic for collective action to occur (Klein and Schellhammer, 2011). Consequently, it becomes necessary to reconcile divergent interests of a group to ensure 
participation (Markus et al., 2006). In contrast, convergent interests amongst a group facilitate cooperation to establish a common good.

The range of technical, financial and organizational resources that are brought in and shared, contributing to establish a common good, are also of importance (Nikayin et al., 2013). The participation of particular actors becomes necessary because of the unique resources that they bring and which are required for the cooperation to work (Markus et al. 2006). The more heterogeneous the distribution of key resources is across the collaborating organizations, the more mutually interdependent they are upon each other in order to establish the common IS good. On occasion, network effects created by the participation of multiple members can be a driver for essential resources such as installed base.

The governance and coordination of organizations contributing to a common IS good emerges as the final key factor. This function is typically carried out under the leadership of a central authority (Markus et al., 2006; Eaton et al., 2014). The task of establishing collective action is concerned with mobilizing an initial group of contributors and initial activities to generate a bandwagon effect (Oliver and Marwell, 2001). The initial group of contributors is often a club with limited numbers of members with homogeneous interests (Foray, 1994). Another set of activities concerns the establishment and management of fora where members can discuss and resolve issues. With these activities comes the need to establish rules or policies to guide interactions and the management of resources (Markus et al., 2006). These fora provide a means by which members can manage each other, for example through "moral suasion" (Eaton et al., 2014), thereby contributing to the governance of the collective.

In conclusion, we examine the emergence of national e-ID across the three Scandinavian countries as a process of financialisation which requires the interaction of both governments and financial actors. By treating national e-IDs as common goods, we can use the lens of collective action in order to investigate how they come into being. In order to do so, these heterogeneous actors must overcome competing interests, coordinate complementary resources and align governance models through a dynamic process of conflict, negotiation and collaboration.

\section{METHOD}

The aim of our study is to explain (Gregor, 2006) how the interaction between financial and public actors influence the emergence of e-ID solutions. With this in mind, we conceptualize e-ID as a common good in accordance with the theory of collective action, which explains the broad conditions under which actors are able to collaborate with each other in order to establish a common good. Our intention is to develop a generalisable process theory (Van de Ven and Poole, 1995) to explain the unfolding of interactions, as a unit of analysis, between financial and public actors in the emergence of shared IT.

Consequently, we conducted a cross-case comparative study (Yin, 1994) in order to be able to infer generalizable insights concerning the phenomenon that we wished to study. In this way we conducted our research broadly in line with Eisenhardt's (1989) approach to building theory from case study research. We chose to study the emergence of e-ID in Denmark, Norway and Sweden. The cases of e-ID emergence in each of these countries contain similarities and subtle differences that lend themselves to theory building (Hansteen et al. 2016). The three countries feature similarities in their high levels of digital literacy and IT penetration, extensive welfare service provision, and socio-economic indicators, and in national administrative and legal traditions. They also display differences in the role that markets have in public policymaking.

In line with our approach to designing this research, our methodological stance is both qualitative and interpretive as we draw upon narrative texts concerning the processes by which 
e-IDs emerge, in order to develop a second-order theoretical understanding of the phenomenon (Walsham, 1995).

\section{Data Collection}

The data for this study was collected from three main sources to trace the emergence of e-ID: 1) online sources including key stakeholder web pages and online press releases; 2) documents, including policy documents, legal framework and associated documents; and (3) interviews with key stakeholders, including 16 top and middle managers, that lasted on average 60 minutes, chosen based on their expertise, in line with the key informant approach (Kumar et al., 1993). The objective was to identify relevant initial conditions, changes, events, and states necessary to capture the emergence of e-ID. Table 1 provides a summary of the data sources.

\section{$<$ Table 1 about here $>$}

\section{Data Analysis}

The aim of our data analysis was to understand how the interaction between financial and public actors influence the emergence of national e-ID solutions and to express this as a simple process model. Our interest was to establish how groups of actors with divergent interests and varied resources engaged in interaction, conflict and negotiation over a period of time, in order to bring about collective action in pursuit of a common good.

We conducted our analysis in three broad steps, with distinct objectives. The first step consisted of "within-case analysis" (Eisenhardt, 1989). Here we applied an open coding procedure to the data in order to familiarize ourselves with the data and capture an event-time series (Pettigrew, 1985) regarding the emergence of e-ID in each of the three cases. Coding categories concerned generic process codes, including events, actions, decisions, and outcomes, to determine concepts (such as phases, technologies, policies, stakeholders, user base etc.) and their properties (e.g., initial/final). The outcome of the first coding step was three timelines depicting the emergence of e-ID in Denmark, Norway and Sweden with an unstructured list of concepts deemed relevant to the unfolding of each story up until the launch of each national eID.

In the second step, we applied a cross case analysis in order to look for patterns across the cases. Consistent with Eisenhardt's (1989) approach, we turned to the theoretical literature in order to provide dimensions around which we could cluster codes from our first phase of analysis. We applied collective action literature as a means to systematically map the various concepts related to the emergence of e-ID, which were identified in the first step, to the three key dimensions required to achieve a common good (interests, resources, governance). In this way, for example, "installed base" became "resources", "legal framework" became "governance", and "24-hour agency" became "interests", so that the three cases could be compared with each other.

In the third and final step, we were able to examine the process of e-ID emergence across the cases, develop a view of overarching patterns across the three cases, and compare this outcome with existing literature (Eisenhardt, 1989) on process theory. In this final stage, we found inspiration in dialectic theories (Van de Ven and Poole, 1995) consisting of three phases: thesis versus anti-thesis; conflict; and synthesis. This enabled us to develop a dialectic process model by tracing the order of events, using the dimensions of collective action and their underlying mechanisms across the three phases of our model. In the next section, we present three narrative cases on the emergence of e-ID in Denmark, Norway, and Sweden.

\section{THE EMERGENCE OF NATIONAL E-ID}




\section{Denmark}

The idea of universal e-ID in Denmark was first presented within the national e-government plan in 1992 (Danish Ministry of Finance, 1992). The Ministry presented the idea of a multipurpose physical ID card, based on smart card technology, to work as a means of offline visual identification, an electronic key for the Central Person Register (CPR), and a tool for the authorities to access personal information. The vision was to eventually replace all other cards, including social security cards, student cards, and driver licenses. The majority in Parliament, who raised privacy concerns, opposed the proposal. A later proposal in 1996 for an optional card for online authentication failed due to the lack of agreement on a technical standard. As a result, the ambitions from then on were reduced to adopting a system of digital signatures, and not a card.

After a change in the political orientation of the government, competencies for egovernment policies were moved to the newly established Ministry of Science, Technology and Innovation. The Ministry published the idea of a "Public Service Net", which gave IT a much more important role in the political discourse than before, but had little practical implications (Johansson, 2004). From 2001 a new government cabinet took over. The Digital Task Force (DTF) was established, a project-based organization hosted by the Ministry of Finance. The DTF coordinates all entities that are involved in e-government (central, regional, local government, and businesses). Up to this period, multiple initiatives for authentication to access public services flourished within the public sector, including a regional health card, and two tax system authentication solutions: one based on a one-time password and one that required the installation of a software on the user's device.

In this period, banks started developing their own solution, known as Net-ID, for access to online banking services. Net-ID was issued by the individual banks under the certification authority of Pengeinstitutternes Betalings Systemer (PBS). The Net-ID solution was developed in isolation from solutions in the public sector, and at this time the banks saw little benefit in cooperating with the public sector in this area.

The government, following the existing EU directive on digital signatures (1999/93/EC), established its own framework for a national digital signature solution (Danish law nr. 417 of May $31^{\text {st }}, 2000$ ) and issued a public tender for the implementation (Cuijpers and Schroers, 2014). During the evaluation two vendors were found particularly attractive. The first was a consortium of banks and PBS who were offering Net-ID. The second was TDC (Tele Denmark Communications), the former national telecom company. After some deliberation, TDC was awarded the contract by the Danish government. The result was a software-based signature for authentication to access online public services. The signature was obtained by entering one's CPR number, postal code, and e-mail address. Activation of the signature required downloading a software on a citizen's device, and using a PIN code sent by physical letter ( similar to the banking Net-ID solution). The roll out of the digital signature was much slower, compared to the banks' Net-ID. In the period 2003-2007 only around 250,000 citizens used this solution, compared to 2.2 million users of Net-ID. The main reason for the low uptake was the absence of a perceived benefit from citizens and businesses, and technical difficulties. For instance, the installation of digital signatures on Mac users was problematic (Hoff and Hoff, 2010).

In 2008, after the contract between TDC and the National Board of IT-and Telecommunications expired, it was time for a new tender. It was won by PBS (later re-named to Nets). The new solution was called NemID ("EasyID” in Danish), and was characterized by: a) possibility to be used as signature for banking services; b) a two-factor identification solution, containing something you know (username/password), and something you get (a one-time password); c) the possibility of logging from multiple devices. 
The solution initially encountered criticism, in particular regarding privacy and security. However, this time, learning from the unsuccessful experience, in order to prevent criticism, the Board of IT and Telecommunications tried to integrate civil society concerns by allowing the IT Political Association and the Danish Consumer Council a role in the choice of software and standards. This co-optation strategy resulted in partially assuaging overall criticisms, even though the IT Political Association left the working group established to create the new standards due to dissatisfaction with the results obtained. Then NemID solution became operational in January 2011, and reached 3.5 million users in March 2011, when other legacy solutions were stopped (OECD, 2016).

\section{Norway}

The emergence of a national e-ID solution in Norway has its roots in the banking industry at the end of the 1990s, when the banks were establishing their own individual e-ID solutions for customer access to online banking services (interview SpareBank 1 01/14). The banking industry, which already had a history of cooperating in shared infrastructure whilst competing at the level of service, came together to discuss building a shared e-ID infrastructure (interview BSK 6/13). The working group came to be known as the BankID Cooperation and the common system they were designing was called BankID. From the start, the BankID Cooperation intended to generate revenues from the sale of BankID capabilities to organizations outside of the finance industry (interview BankID 01/14).

In mid-2000, the BankID Cooperation prepared a draft of standards for architecture and interfaces, and associated rules and regulations for governing the proposed structure. A year later the plans received approval by the banks, and BankID was set up as an official project. Nets AS, which already managed the banks' other shared infrastructures and services, was appointed to build and operate the cloud infrastructure needed to run BankID (interview BSK 9/13). The Norwegian bankers' association oversaw the design and implementation. By June 2003 the common BankID infrastructure was largely in place and began distributing one-time password tokens to its customers toward the end of 2004 (BankID Nyheter 30/12/2004).

Government interest in e-ID for access to government services resulted in a request for information from potential suppliers in 2003. The government followed this up in 2004 by publishing specifications for a national e-ID solution, requesting compliance with the data encryption, as set out in European standards in conformance with EU directive 1999/93/EC concerning electronic signatures (interview BSK 9/13). The BankID Cooperation stated in early 2005 that it sought to become part of the government secure ID solution (BankID Nyheter $15 / 12 / 2006$ ). Being able to play part of such a solution was not only consistent with the banks' goal of generating revenues from BankID, but was also a means of growing and securing its user base.

What followed was 8 years of government indecision as the government prevaricated between developing a standalone government solution for e-ID and adopting a commercial solution. At the heart of the debate concerning the government's adoption of BankID were two factors (interview BSK 11/2013). The first was a disagreement over what security standards to employ. Over time, European standardization efforts had diverged from what was implemented in BankID. These newer standards were more secure than those already implemented by the banks. Updating the existing BankID infrastructure to support these standards would have required investment that neither the banks nor the Norwegian government was willing to pay. The second factor concerned politics and the attitude that a Norwegian government of the day has towards cooperating with banks for e-ID solutions. Left leaning governments preferred to avoid cooperating with banks and investing taxpayer money in a government-only solution. Right leaning governments preferred not to invest large amounts of public funds in e-ID infrastructure, and were more open to cooperating with banks. 
BankID grew its user base to over 3 million and was increasingly demonstrating its success. From its launch in 2005 it had widely been adopted by local government, regional health authorities, and the Norwegian Postal Service. All the while the BankID Cooperation was approaching the government whenever it opened up to the notion of adopting a commercial solution. Each time it was turned down on account of not meeting the government's specifications concerning encryption. The public and the press met these decisions with increasing frustration (BankID Nyheter, 16/04/2010).

Finally, in April 2012, the Norwegian government opened up a tendering process for secure electronic identity to access online public services once more (BankID Nyheter 11/04/2012). In November 2012 the government announced that it had signed contracts with a number of commercial suppliers including BankID (BankID Nyheter 14/11/2012). The result of this process was that Norwegian citizens have the choice of three commercial e-ID solutions (BankID, Buypass and Commfides), as well as an existing government legacy solution (MinID) when accessing digital government services.

\section{$\underline{\text { Sweden }}$}

e-IDs in Sweden originated from the time when Swedish banks started to launch Internet banks. On the $29^{\text {th }}$ of November 1996, the bank Östgöta Enskilda Bank called a press conference to announce the first "real" Internet bank in Sweden, where customers could pay bills and transfer money from one bank account to another. Over the next 400 days all other major banks had opened an Internet bank (Sandén, 1999).

At this time, a range of different groups owned the banks. One originated from the cooperative movement, another was linked to the government and the postal office, and two others were linked to different industry groups. Whilst there was some collaboration between the banks (Andréasson, 2011; Wihlborg, 2013) regarding OCR codes used to identify invoices in the invoice payment clearing system - the Giro system - overall collaboration was limited.

The Swedish government's interest in e-ID was initially limited. The only government initiative, at this early stage, was that Sweden ratified the European Parliament and Council Directive 1999/93 / EC on a Community framework for electronic signatures. The one exception was the tax authority, who was interested in enabling citizens gain online access to file taxes. The tax authority also provided a key authentication component, namely the unique CPR number used by all individuals to identify themselves with the state (Gustafsson and Wihlborg, 2013). The CPR number was also used by the banks and linked to the national address registry (SPAR).

e-ID only emerged on the government's agenda in 2001, when Sweden held the presidency of the EU. Politicians started to talk about the " 24 hour government" (Söderström, 2012). The tax authority was given the initial responsibility to investigate the area. They began to look to the part of society that had the largest electronic customer base. Later that year, it was decided that Sweden's approach towards e-ID should be based upon a framework agreement (VERVA, 2008). The framework stipulated that e-ID providers were responsible for issuing e-ID, managing agreements and contracts with the citizens, and providing the technical infrastructure. During these years a new agency, called Verva, was formed, with the responsibility to oversee e-ID (VERVA, 2008).

Banks, together with one mobile operator, were appointed as issuers of e-ID. The government and the individual authorities, in turn, were to buy e-ID verification service from the respective issuer. VERVA's framework agreement was in force until June 30, 2008. Meanwhile, the banks had initiated a dialogue within their industry. A consortium was formed and most of the banks were involved. The aim was to develop a general infrastructure for e-ID, which could meet the requirements of the government and the banks. In September 2002, they formed Financial ID-Teknik BID AB, where the results of the consortium's efforts were placed. 
The first e-ID (named BankID) was issued in 2003. The banks were still running their authentication solutions independently. The tax authority and social security were quick to adopt BankID and would be the driver for the increasing use of e-IDs. Over the years a growing number of banks began to issue BankID. The stakeholders created a forum for individuals to discuss e-ID (e-legitimation.se). In 2006, the three issuers of e-ID were the banks issuing BankID, Nordea and TeliaSonera.

In 2010, BankID on mobile was launched. The two mobile operators TeliaSonera and Telenor were involved in the development. The first BankID on mobile was cancelled in 2011 and replaced by Mobile BankID for mobile phones and tablets. Mobile BankID worked with any mobile device and Internet operator. In the following year, the bank's launched a new mobile payment service (SWISH) for person-to-person payments, which quickly became a success. Mobile BankID is used as the authentication method in this solution.

In January 2011, Nordea joined Financial ID Technology and started to issue BankID and thereby cancelled their own e-ID service. The same year, the E-identification Board started its work with the aim to introduce an electronic identity card (e-IC) by 2016. The banks are involved. In 2015, the Administrative Court, based on the Personal Data Act, forced schools to require e-ID instead of only username and password. During 2015, approximately 1.2 billion transactions to be made with a Bank ID, and Mobile BankID has become the main e-ID for many.

\section{CASE ANALYSIS}

In this section we present our analysis and show how the interaction between financial actors and governments has influenced the emergence of e-ID across Denmark, Norway, and Sweden. We start by a cross case analysis and identify differences in the way they play out in each country. We then apply the lens of collective action to interpret the differences in how the balance of converging and diverging interests, how the shift in resources from independent to interdependent, and how governance structure influenced the process over time. In applying collective action, we identify dynamics between governance structures, the interdependency of organizational and technical resources, and changing interests, which we theorise as a dialectic process model of the evolution of e-ID based on the three cases.

\section{Cross-country comparison}

The emergence of national e-ID across the countries appears to follow three phases: first, the establishment of precursors to national e-ID; second, debates that occur agreeing the form and nature of e-ID; and third, the roll out of national e-ID. Although the timing and duration of these phases differ, the outcome is broadly the same. Whilst the fact that these national e-ID infrastructures share common phases in their emergence may not be unusual, these phases provide an opportunity to identify the similarities and differences between the three cases. These will be later used to analyse the transformation of interests, resources and governance of relationships between banks and governments over time.

In all three countries the banks establish their own e-ID solutions before the emergence of a national e-ID. In both Denmark and Norway, the banks establish a common e-ID solution. These solutions enable banks in these countries to cooperate at the level of infrastructure to derive cost savings, but compete at the level of service. The banks team up with infrastructure partners and they seek to derive revenues from selling e-ID capabilities to other stakeholders. The actions of the Danish and Norwegian banks reflects an established history for banks in these countries to cooperate on infrastructure. In contrast, in Sweden the banks did not cooperate to establish a common e-ID solution in this phase. The Danish government is more proactive in establishing its own solution. The Norwegian and Swedish governments are slower to establish plans. However, it is soon clear that all three governments see the benefits of 
cooperating with the banks to establish e-ID, in order to benefit from the installed base and familiarity of use that the banks have established with their e-ID solutions.

The governments of all three countries then go through a period of dialogue with the banks on what the form and nature of a financialized national e-ID system should take. The Danish government agrees a common solution with the banks relatively quickly after a short tendering process. The Norwegian government engages in a protracted on-off tendering process that lasts eight years, after which the banks' solution, whilst being the most popular with citizens, is one of four chosen solutions (one being the government's legacy solution, the other three being commercial solutions). In both these cases, the government and the banks have disagreements over which security standards they use. In contrast, in Sweden the government struggles to get the cooperation of the banks, as they initially refuse to work with each other.

Finally, a system of financialized e-ID is rolled out, in one form or another, in all three countries. The governments and banks in Denmark and Norway are able to come to differing architectural solutions in order to overcome differences in security standards demanded. The Danish government mandates NemID as the only e-ID solution. The Norwegian government allows four different solutions to be made available to its citizens, of which Norwegian BankID has the greatest penetration amongst citizens and is by far and away the most used. The Swedish government follows a more laissez faire approach, allowing competing vendors to organize themselves, resulting in a much slower emergence of Swedish BankID and a slower citizen take up of digital government services. As a consequence, financialized national e-ID reached widespread adoption in Denmark and Norway by 2012. In Sweden national e-ID has to become a necessity with the widespread adoption of SWISH, a mobile real time payment system, which uses Swedish BankID as a means of identification and authentication.

In the following section we articulate these three phases of emergence of a financialized e-ID solution using the lens of collective action theory, by focusing on the role of interests, resources, and governance at each phase.

\section{Interests, Resources and Governance}

We see the emergence of a national e-ID solution as an example of financialization and the establishment of a common IS good, which comes about as a result of the interaction between the financial sector (the banks) and the government. We focus on the role of interests, resources, and governance, using the collective action theory as an interpretative lens to understand the emergence of this common IS good. We summarize the findings of our cross case analysis in Table 2.

\section{$<$ Table 2 about here $>$}

\section{Phase one: Common e-ID Solution Not Considered}

Interests. In the first phase the banking sector and the government featured interests that were not aligned. The governments in all three countries were developing the vision of a national eID system for their citizens to access e-Government services, pursuing their overall interests embedded in the e-government policy plans. Their interests concern maintaining democratic legitimacy, by aiming at providing universal citizen access to digital services, and enabling efficiency, by aiming at cost-saving through streamlining of administrative processes. On the other hand, banks in Denmark and Norway, in developing their own shared authentication infrastructures pursued other interests. These concerned leveraging economies of scale and being able to generate revenue from other businesses wishing to use the system with a large installed base of users. In Sweden the banks did not have any shared interests as they did not have the tradition to cooperate with each other. 
Resources. It this early phase there was no significant interdependency of resources between the respective governments and the banking sector with respect to a common e-ID infrastructure. The banking sector was, however, reliant on the CPR assigned by the governments as a means of identifying users accessing banking services. For the rest, the two actors did not depend on each other's resources at this phase. The government's main resource was the power of legislation, through which to potentially establish the mandatory adoption of digital signatures by the different public agencies. The banking sector's main resource was their common ownership of financial infrastructure providers, for the design, build and management of their online authentication solutions. Such a shared infrastructure did not exist within the Swedish banking sector.

Governance. As the governments and the banks in the Scandinavian countries were not yet cooperating, there were no structures in place between these two sides with respect to the governance of a common e-ID. However, the banks had their own governance structures in place, mediated by their respective bankers' associations.

\section{Phase two: Common e-ID Solution Desired}

Interests. The governments and banks in the respective countries entered discussions regarding common national e-ID systems. This was driven by the governments' vision of providing citizens with e-ID, and the banks' interests were driven by economies of scale and potential for increased revenues. However, discussions in Denmark and Norway were difficult with respect to which security standards to employ. Moreover, in Norway ideological motivations held the government back from further engaging in embracing a privately-owned solution for e-ID.

Resources. The interdependency of resources between government and the banking sector remained similar at this phase. While resources related to government and bank e-ID solutions remained strictly independent of each other, in all three countries the governments realized the need for a growing user base for online authentication systems, which banks managed to build up more quickly than the public sector agencies.

Governance. In Denmark and Sweden, the respective governments established frameworks for the governance of national e-ID. In Denmark this took the form of a national law that is built on EU directives. In Sweden the government established a governmental agency, Verva, that manages a framework for cooperation between the banks and government based on the EU directives. In Norway no governance structure is established between the two sides, as the government prevaricated as to how a national e-ID solution should be delivered.

\section{Phase three: Common e-ID Achieved}

Interests. In this third phase, the interests of the national governments and banking industries converge sufficiently for national e-ID systems to be put in place. The key areas where their interests had diverged were overcome with compromise on both sides. In Norway, the government overcame its ideological concerns about being dependent on a single commercial supplier, by opting to adopt a range of solutions provided by different parties, and letting individual Norwegian citizens choose which one they preferred. In both Denmark and Norway, the parties were able to find solutions for their differences over security standards. In Sweden the banks overcome their divergent interest in sharing e-ID infrastructure amongst themselves, and with the government, as the result of their common interest in another emerging shared infrastructure around SWISH, a common mobile real time payment system.

Resources. An increasing interdependency of resources between governments and the financial sector influenced the launch of national e-ID systems across the three countries. In Denmark the two sides share a common e-ID user interface. The Danish government found itself dependent on the resource of a wide user base held by banks, while banks developed the need for government's support for expanding the range of application of their authentication 
system to include digital public service access, and third-party commercial applications. In Norway, the two sides are now more dependent on each other for resources, but only up to a point. The Norwegian government, which wanted to avoid over-dependency on the banks' solution, ended up adopting four different e-ID solutions. Consequently, the Norwegian banks benefit from the revenues that they were making from the government's use of BankID under a commercial relationship. The Norwegian government were benefiting from the installed base of BankID users to drive up usage of e-government services. In Sweden, whilst several e-ID solutions still exist for access to e-government, Swedish BankID is growing its installed base, driven by SWISH, and is becoming the default solution.

Governance. With the emergence of e-ID in each of the countries, different types of governance solutions are put in place between the government and the banks. These are driven by government in Denmark, by commercial agreements and consumer choice in Norway, and by banks shaping the market in Sweden. In Denmark, the government drives the governance of NemID, the national e-ID solution. Within the legal framework of the regulations drafted by the Danish government to enforce requirements for the tender winners, the government and the banks swiftly established a mechanism based on cooperation. The infrastructures for online banking and digital public services are coordinated under a certification authority, maintained by the bank consortium that won the current tender, and ultimately lead by government requirements renewed at every tender cycle. In Norway, the government eventually opted to adopt a range of solutions provided by different parties, including the Norwegian Banks and their BankID solution, and letting individual Norwegian citizens choose which one they preferred. The Norwegian government established a commercial relationship with each of the private suppliers, paying them by the number of e-ID transaction that they enable in a given period. In this way the Norwegian government was not entirely dependent on the banks for the supply of e-ID infrastructure. In Sweden, the government decided to let the market forces play, but enforced some requirements on the market through framework agreements.

\section{A Dialectic Process Model}

The establishment of a common good takes time. It involves the interplay between interests, resources, and governance of relationships between the financial sector and government in the emergence of national e-ID solutions, and can be conceptualized as a process model. In particular, the three phases of transformation in the three dimensions that shape collective action assume the form of a dialectic process (Van de Ven and Poole, 1995). The dialectic nature of this process is evident when looking at the three phases of transformation: first, as thesis and anti-thesis when the two groups of actors do not consider a common good and are engaged in parallel developments, each with its own separate configurations of interests, resources, and governance; second, as conflict when the two parties desire a common good, but disagree on how their interests, resources and approach to governance can be aligned; and third, as synthesis when the parties resolve tensions across the dimensions of interests, resources and governance, and a common good can be achieved. Our dialectic process model is represented in Figure 1.

\section{$<$ Figure 1 here $>$}

The period of time that elapses in the respective phases varies across the three cases, but the fundamental dynamics between the dimensions of collective action are similar. In the first phase, when government and banks have not yet considered a common e-ID system, each group focusses on its own e-ID plans. Here collective action is not realized between the two parties, but within the members that make up each group. The banks' e-ID solutions are characterized by an interdependency of technical, organizational and installed base resources, 
driven by convergent economic interests, i.e. scale of the investment, and organized by their own particular governance arrangements. The governments' plans are organized around financial and bureaucratic resources driven by an interest in establishing universal Internet access to government services, i.e. use of the installed base - for all the citizens, and organized through government agencies and policy.

In the second phase government and banks begin to recognize a desire for a common eID solution. However, proposals for a combined solution lead to conflict across the dimensions of collective action that we consider. They cannot agree on a common infrastructure as their divergent interests around security standards and ideology and their disagreements about overarching governance models prevent them from sharing resources, which remain independent.

Finally, in the third phase the government and banks are able to achieve realizable plans for a common e-ID solution. The common e-ID solution is characterized by an interdependency of e-ID infrastructure and installed base of users. This interdependency is reached as their interests converge in issues concerning security standards, ideology, economic benefits, and enabling universal Internet access to government services. Both the convergence of interests and interdependency or resources is facilitated by agreed overarching models of governance.

What is of interest is that the contextual conditions specific to each of the three countries is such that they find different approaches to governance to help them realize systems of national e-ID. In Denmark, the governance regime is driven by government regulation. In Norway, the government establishes commercial agreements with a number of e-ID suppliers, including the banks, to govern the management of national e-ID. In Sweden, the government allows the provision of national e-ID to be market-driven, meaning that various suppliers, including the banks, can simply emerge.

We see different mechanisms which facilitate the transition from one phase to another across our dialectic process model. The banks were able to transition from a phase where they were not considering participation in a national e-ID solution, to a second phase where they were driven by a desire to establish cost savings through economies of scale and the potential of additional revenues, as well as a realization that they could retain control of assets central to their e-ID solutions. Similarly, the governments transitioned across the two phases once they realized that access to the banks' installed base of users, combined with the public's familiarity with the banks' authentication processes, would encourage the public's access to government services. Furthermore, it was the ability of the parties to compromise over the architectural approach to realising common infrastructure and the way that it is governed that enabled them to realize a national e-ID solution.

\section{DISCUSSION}

We find that the creation of common good in the shape of national e-ID emerge as the result of the convergence of interests and interdependency of resources between the actors over time. There are different paths or ways of "skinning the cat" leading to collaboration between the financial and the public sector to realise a common IT, and they depend on the distribution of interests and resources amongst actors. In this section, we first discuss how the dialectic process of thesis, anti-thesis and synthesis presented in our model advances our understanding of the financialization phenomenon. Then, we focus our attention on the five mechanisms that drive the process of financialization.

\section{The dialectics of financialization}

We model the establishment of a national e-ID as a dialectic process with thesis, anti-thesis and synthesis (Van de Ven and Poole, 1995). Here the diverging interests of the financial sector and the public sector converge in the common goal of establishing a common good, as experiences 
with e-ID accumulate over time. Resources across the actors transform from being independent to being interdependent, meaning that they become shared assets. Different models of governance emerge across the three examined cases, which implies that contextual variables still play a role in the unique instances of this dialectic process, resulting in three different ways to "skin the cat".

Our dialectic process model view provides three new angles on the phenomenon of financialization. First, our study provides a process view, whereas financialization has so far mainly been considered from a variance model perspective. Existing research on financialization, largely informed by Marxist political economy (Lapavitsas, 2013), has mainly focused on theorizing its systemic causes, by focusing on the different features of capitalist societies. Such causes include: the increasing need of corporations to channel surplus value that cannot be easily re-absorbed through consumption and investment by the productive sector anymore (Foster, 2007); the response of the state to economic crisis conditions (Krippner, 2011); the decline of hegemonic powers in the capitalist world economy (Arrighi, 2007); the ineffectiveness of central banks' measures to counteract falling rates of profit (Brenner, 2009). This dominance of a variance model approach reveals a gap in theorizing processes of financialization in action over time. Our dialectic process model, by modelling the stages of interaction between financial and public actors in the emergence of the e-ID, aims at tackling this gap. Through evidence from our cases we put forward that, far from being a linear process, the financialization phenomenon can be conceptualized as a dialectic one.

Second, our study adopts a circumscribed unit of analysis - the one of interactions between individual (and groups of) banks and governmental agencies, in the specific area of public identification systems - in investigating financialization. Existing research on financialization has mostly adopted large-scale, or very large-scale, units of analysis, such as the world economy (Arrighi, 2007; Brenner, 2009; Epstein, 2005), clusters of national economies (Painceira, 2012), and national economies (Krippner, 2011). Our focus on groups of actors within a limited time and geographical frame enabled us to theorize financialization at an under-investigated, lower level of abstraction.

Third, our study puts an IT process at the core of the financialization phenomenon, by conceptualizing it as an area in which instances of financialization unfold. While a number of studies have focused on the establishment of IT as the product of collective action (Markus et al., 2006; de Reuver et al. 2015), to the best of our knowledge, to this day financialization in the form of IT collaboration has not been object of study.

\section{The mechanisms of financialization}

By applying the theory of collective action (Markus et al., 2006; de Reuver et al., 2015), this study provided a longitudinal view of how interests, resources, and governance change over time in the interplay between actors (financial and public), resulting in the emergence of a common good. We identify five mechanisms, economics of scale (i.e., control of assets, installed base, compromise of architecture, and compromise of governance) that drive changes in the dimensions of interest, resources and governance between the three phases that make up our dialectic process model.

Mechanisms that enable the transition from the first to the second phase play out differently for the banks and government. For the banks these concern economies of scale as well as agreement by the government to the banks retaining control of technical assets. Economies of scale relate to banks wanting to increase the user base of their technology and thereby reduce the unit costs of development. This follows principles from strategy theory to achieve low cost advantages in the use and development of IT (Porter, 1980; 1985; Drnevich and Croson, 2013). Furthermore, an additional concern for the banks was to "control" the technology and customer data needed to authenticate access to banking infrastructure. This was 
needed primarily to ensure their competitive advantage as well as the privacy and thereby trust of their customers. This focus on internal assets (Barney, 1991; Bharadwaj, 2000) assumes that banks want to control their "idiosyncratic and firm-specific sets of imperfectly mobile resources" (Hedman and Kalling, 2003: 50) to gain differentiation. Early government e-ID solutions faced the problem of low adoption, since they were used infrequently, and citizens did not familiarise themselves with how they worked. In order to grow their installed base of users, the governments bootstrapped (Hanseth and Aanestad, 2003) onto the bank e-ID solutions which were widely used.

The mechanisms that allow for the transition from the second to the third stage are shared by both sides. First, these concern the agreement to compromise over the adoption of particular security standards in the technical architecture. Second, these involve the agreement to compromise over the adoption of particular forms of governance of the collaboration. Compromises of this nature, which are required to grow an installed base, are recognised in the information infrastructure literature (Aanestad and Jensen, 2011; Braa et al., 2007). It follows then that our study would identify these mechanisms at play in the evolution of shared e-ID solutions, which display the characteristics of information infrastructures as a shared, open, heterogeneous and evolving installed base of IT capabilities, users and design communities (Hanseth and Lyytinen, 2010). Finally, the mechanisms of compromise reflect the dialogues and negotiations that took place in all three countries and show key democratic principles coming into play when creating a common good. It is during the period of the emergence of this national e-ID solutions that New Public Management (Osborne et al., 2013) entered the space of public governance. Accordingly, making compromises between the private and public sector became much more acceptable in the public eye. This is also seen, for instance, in the growth of public service platforms in Sweden, where most public services today use market pricing mechanisms (Ranerup et al., 2016).

\section{Implications and future research}

The findings from the study have implications for both research and practice. Regarding research, this study contributes to the extant literature in several ways. First, by filling a gap in understanding effects of financialization that go beyond the area of economic behaviour, such as different regimes of accumulation (Krippner, 2005), and modes of management of the firm (Fligstein and Shin, 2004; Lin and Tomaskovic-Devey 2013) by focusing on how financialization in public policy-making is influencing the development of a public IS good and, potentially, of IT in general, such as blockchain systems, automated auditing systems and compliance systems (Gozman and Currie, 2014).

Second, by analysing the emergence of national e-ID as a public good stemming from collective action, it sheds light on the under-investigated area of how financialization influences public IT development. The dialectic process model contributes to refining the theoretical lens of collective action, by accommodating a process view on the interplay between actors leading to collaboration over time, as opposed to a still representation of the role of interests, resources, and governance (Constantinides and Barrett, 2014). Furthermore, the dialectic model contributes to a conceptualization of the interplay between actors that shape the emergence of a collaborative IT project - e.g., how IT becomes implemented and absorbed in organizations or in society - in contrast with the assumption of the importance of top-management decisions that dominates much IT research (e.g. Wixom and Watson, 2001). The mechanisms we identify provide details on what drives a collective action process of financialization forward. Whilst some studies (e.g. Constantinides and Barrett, 2014) have previously used collective action as a theoretical lens as a means to examine the evolution of an information infrastructure, they have typically focussed on one particular mechanism. Our study reveals that an interplay of a range of mechanisms is needed in order for a common good to emerge. For instance, there is a 
need for the actors to gain something, such as scale of assets, technology and user base (Nikayin et al., 2013; Oliver and Marwell, 2001), from the collective effort to develop a common good. However, even bankers and governments have no free lunch: the gains come with a cost, namely the compromises regarding architecture and governance.

Third, our study complements the extant body of research on e-ID solutions, which so far have been analysed from the perspective of technological decision (Whitley and Hosein, 2008), trust and public value (Seltsikas and O'Keefe, 2010), and market governance (Grönlund, 2010); but very rarely as the outcome of the interactions between different classes of actors; and never as an instance to investigate the phenomenon of financialization and IT. Furthermore, our study is one of the first to include multiple cases.

Regarding practice, findings from our study have implications for both public and financial organizations' management engaged in collaboration related to common IT goods. Based on our findings, we put forward that during the key phase of transition from divergent to convergent interests and from independence to interdependency of resources between actors, it is of crucial importance to find ad hoc mechanisms of governance, as opposed to "one size fits all" governance solutions. As the cross-country comparison of this study clearly shows, the conflict and negotiation phases throughout the dialectic process of achieving a common good are an integral part of the process of aligning interests and resources, which can also take long periods of time. However, the parties involved should pursue specific governance arrangements that fit the nature of the interests and resources involved, rather than trying to adapt them to a pre-defined governance template. The evidence from the variety of successful ways of "skinning the cat" of a large IT infrastructure collaboration in this study shows that there are varying governance modes that can be adopted by managers to successfully accommodate the transformation of interests and resources.

As with any research, ours is subject to limitations. The cases provide ample basis for analysing the relationship between the stakeholders. However, the cases do have some limitations. First, a limitation in the generalizability of the proposed process model needs to be pointed out. We put forward that our process model is generalizable to processes of financialization involving the development of a common IS good. Such a limitation is in line with the fact that we did not aim at providing generalizable findings applicable to other empirical settings, but rather at investigating theoretical concepts and principles that could be applied in similar contexts (Lee and Baskerville, 2003). Second, we focused only on e-ID as one component in the financialization phenomenon: we acknowledge that there are other aspects of financialization, such as mobile payments, real-time payments, biometric authentication, and automated auditing systems, all worthy of further research in order to gain a deeper understanding of the role of IT in such processes. Such a conceptualization can help frame processes of collective action in future studies on the intersection between financialization and collaborative IS development.

\section{CONCLUSION}

The growing phenomenon of financialization influences an array of societal dimensions that go beyond the economic realm, to include public policy making and collaboration in public IT. In this study, we aimed at answering the research question "How does the interaction between financial and public actors influence the emergence of national e-ID solutions?" by conducting a cross-country analysis of the emergence of national electronic identification (e-ID) solutions as the result of interaction between the financial and the public sector.

Our findings show that different governance solutions can emerge as the result of the convergence of interests and interdependency of resources between the actors over time: there are different ways to "skin the cat" of collaboration between the financial and the public sector in shared IS solutions, and they are dependent on the distribution of interests and resources 
amongst actors. The dialectic process model we propose aims at conceptualizing different paths towards collaboration, and provide a stepping-stone for further unboxing the under-investigated intersection of financialization and IT.

\section{ACKNOWLEDGEMENT}

The authors would like to thank Telenor Research and Future Studies for the funding that made this research possible. We are indebted to those we interviewed for their interest, help and support. Special thanks to Frances D'Silva at Nets Norway AS, who was instrumental in helping to establish this study.

\section{REFERENCES}

Aanestad, M. and Jensen, T.B. (2011). Building nation-wide information infrastructures in healthcare through modular implementation strategies, The Journal of Strategic Information Systems 20(2): 161-176.

Andréasson, E. (2011). Utvecklingen av e-legitimationer i Sverige - en studie av det privata och det offentligas roller, Presented at the Statsvetenskapliga förbundets årsmöte, 28 October 2011, Umeå, Sweden.

Arrighi, G. (2007). Adam Smith in Beijing: Lineages of the twenty-first century, London: Verso.

Barney, J. (1991). Firm Resources and Sustained Competitive Advantage, Journal of Management 17(1): 99-120.

Bharadwaj, A. (2000). A Resource-based Perspective on Information Technology Capability and Firm Performance: An Empirical Investigation, MIS Quarterly 24(1): 169-196.

Braa, J., Hanseth, O., Heywood, A., Mohammed, W. and Shaw, V. (2007). Developing Health Information Systems in Developing Countries: The Flexible Standards Strategy, MIS Quarterly, 31(2): 381-402.

Brenner, R. (2009). The Economics of Global Turbulence, London; New York: Verso.

Constantinides, P. and Barrett, M. (2014). Information Infrastructure Development and Governance as Collective Action, Information Systems Research 26(1): 40-56.

Cuijpers, C. and Schroers, J. (2014). eIDAS as guideline for the development of a pan European eID framework in FutureID (Vol. 237, pp. 23-38). Presented at the Open Identity Summit 2014, Gesellschaft für Informatik.

Danish Ministry of Finance (1992). Effektiv EDB i staten. Copenhagen: Danish Ministry of Finance.

Davis, G.F. (2009). Managed by the Markets: How Finance Re-Shaped America. Oxford: Oxford University Press.

de Reuver, M., Verschuur, E., Nikayin, F., Cerpa, N. and Bouwman, H. (2015). Collective Action for Mobile Payment Platforms: A Case Study on Collaboration Issues between Banks and Telecom Operators, Electronic Commerce Research and Applications 14(5): 331-344.

Drnevich, P. and Croson, D. (2013). Information Technology and Business-Level Strategy: Toward an Integrated Theoretical Perspective, MIS Quarterly 37(2): 483-509.

Eaton, B., Hallingby, H.K., Nesse, P.-J. and Hanseth, O. (2014). Achieving Payoffs from an Industry Cloud Ecosystem at BankID, MISQ Executive 13(4): 223-235.

Eisenhardt, K.M. (1989). Building theories from Case Study Research, Academy of Management Review 14(4): 532-550.

Epstein, G. A. (2005). Financialization and the World Economy, Cheltenham, UK: Edward Elgar. 
Erturk, I. and Solari, S. (2007). Banks as Continuous Reinvention, New Political Economy 12(3): 369-388.

Erturk, I., Froud, J., Johal, S., Leaver, A. and Williams, K. (2007). The Democratization of Finance? Promises, Outcomes and Conditions, Review of International Political Economy 14(4): 553-575.

Fligstein, N. and Shin, T. (2004). The Shareholder Value Society: Changes in Working Conditions and Inequality in the U.S., 1975-2000, in K. Neckerman, (ed.) Social Inequality, New York: Russell Sage Foundation, pp. 401-432.

Foray, D. (1994). Users, Standards and the Economics of Coalitions and Committees, Information Economics and Policy 6(3): 269-293.

Foster, J.B. (2007). The Financialization of Capitalism, Monthly Review 58(11): 1-11.

Foster, J.B. (2010). The Financialization of Accumulation, Monthly Review 62(5): 1-17.

Gozman, D. and Currie, W. (2014). The role of Investment Management Systems in Regulatory Compliance: A Post-Financial Crisis Study of Displacement Mechanisms, Journal of Information Technology 29(1): 44-58.

Gregor, S. (2006). The Nature of Theory in Information Systems, MIS quarterly 30(3): 611642.

Grönlund, Å. (2010). Electronic Identity Management in Sweden: Governance of a Market Approach, Identity in the Information Society 3(1): 195-211.

Gustafsson, M. and Wihlborg, E. (2013). Safe on-line e-services Building Legitimacy for egovernment: A Case Study of Public e-services in Education in Sweden, eJournal of eDemocracy and Open Government 5(2): 155-173.

Hanseth, O. and Aanestad, M. (2003). Design as bootstrapping. On the evolution of ICT networks in health care, Methods of information in medicine 42(4): 384-391.

Hanseth, O. and Lyytinen, K. (2010). Design theory for dynamic complexity in information infrastructures: the case of building internet, Journal of Information Technology 25(1): $1-19$.

Hansteen, K., Ølnes, J. and Alvik, T. (2016). Nordic Digital Identification (eID). Nordic Council of Ministers.

Hardie, I. and Howarth, D. (2009). Die Krise but not La Crise? The Financial Crisis and the Transformation of German and French Banking Systems, Journal of Common Market Studies 47(5): 1017-1039.

Hedman, J., and Kalling, T. (2003) The Business Model Concept: Theoretical Underpinnings and Empirical Illustrations, European Journal of Information Systems 12(1): 49-59.

Hedström, K., Karlsson, F. and Söderström, F. (2016). Challenges of Introducing a Professional eID Card within Health Care, Transforming Government: People, Process and Policy 10(1): 26-46.

Hoff, J.V. and Hoff, F.V. (2010). The Danish eID Case: Twenty years of Delay, Identity in the Information Society 3(1): 155-174.

Johansson, S. (2004). Lokaldemokrati i informationsalderen, in J. Hoff (ed.) Danmark som informationsamfund. Muligheder og barrierer for politik og demokrati, Aarhus: Aarhus Universitetsforlag, pp. 226-250.

Klein, S., and Schellhammer, S. (2011). Developing IOIS as collective action: a crosscountry comparison in the health care sector, in Proceedings of the IEEE Hawaii International Conference on System Sciences (Kauai, USA).

Krippner, G.R. (2005). The Financialization of the American Economy, Socio-Economic Review 3(2): 173-208.

Krippner, G.R. (2011). Capitalizing on Crisis, Cambridge, MA: Harvard University Press. 
Kubicek, H. (2010). Introduction: Conceptual Framework and Research Design for a Comparative Analysis of National e-ID Management Systems in Selected European Countries, Identity in the Information Society 3(1): 5-26.

Kubicek, H. and Noack, T. (2010). Different Countries-Different Paths Extended Comparison of the Introduction of eIDs in eight European Countries, Identity in the Information Society 3(1): 235-245.

Kumar, N., Stern, L. W. and Anderson, J.C. (1993). Conducting Interorganizational Research Using Key Informants, Academy of Management Journal 36(6): 1633-1651.

Lapavitsas, C. (2013). Profiting without Producing: How Finance Exploits us all, London: Verso Books.

Lee, A.S. and Baskerville, R.L. (2003). Generalizing Generalizability in Information Systems Research, Information Systems Research 14(3): 221-243.

Lentner, G.M. and Parycek, P. (2016). Electronic identity (eID) and Electronic Signature (eSig) for eGovernment Services - A Comparative Legal Study, Transforming Government: People, Process and Policy 10(1): 8-25.

Leyshon, A. and Thrift, N. (2007). The Capitalization of Almost Everything - The future of Finance and Capitalism, Theory Culture \& Society 24(7-8): 97-115.

Lin, K.-H., and Tomaskovic-Devey, D. (2013). Financialization and U.S. Income Inequality, 1970-2008, American Journal of Sociology 118(5): 1284-1329.

Lyon, D. (2009). Identifying Citizens: ID cards as Surveillance, Cambridge, UK: Polity Press.

Markus, M.L., Steinfield, C.W., Wigand, R.T. and Minton, G. (2006). Industry-wide Information Systems Standardization as Collective Action: The Case of the U.S. Residential Mortgage Industry, MIS Quarterly 30(1): 439-465.

Medaglia, R., Hedman, J., and Eaton, B. (2017). Public-Private Collaboration in the Emergence of a National Electronic Identification Policy: The Case of NemID in Denmark, Proceedings of 50th Hawaii International Conference on System Sciences (Kauai, USA). IEEE.

Melin, U. Axelsson, K. and Söderström, F. (2016). Managing the Development of e-ID in a Public e-service Context: Challenges and Path Dependencies from a Life-cycle Perspective, Transforming Government: People, Process and Policy 10(1): 72-98.

Nikayin, F. (2014). Common Platform Dilemmas: Collective Action and the Internet of Things. PhD Thesis. Delft University of Technology.

Nikayin, F., De Reuver, M. and Itälä, T. (2013). Collective action for a Common Service Platform for Independent Living Services, International Journal of Medical Informatics 82(10): 922-939.

OECD (2016). NemID - Danish National eID and digital signature scheme. Retrieved March 10, 2016, from https://www1.oecd.org/governance/observatory-public-sectorinnovation/innovations/page/nemiddanishnationaleidanddigitalsignaturescheme.htm\#t ab_implementation

Oliver, P.E. and Marwell, G. (2001). Whatever Happened to Critical Mass Theory? A Retrospective and Assessment, Sociological Theory 19(3): 292-311.

Olson, M. (1965). The Logic of Collective Action: Public Goods and the Theory of Groups, Boston: Harvard University Press.

Osborne, S. P., Radnor, Z., and Nasi, G. (2013). A New Theory for Public Service Management? Toward a (Public) Service-Dominant Approach, American Review of Public Administration 43(2): 135-158.

Ostrom, E. (2014). Collective action and the evolution of social norms, Journal of Natural Resources Policy Research 6(4): 235-252. 
Painceira, J.P. (2012). Developing Countries in the Era of Financialisation: From DeficitAccumulation to Reserve-Accumulation, in S. Budgen, S. Edwards, M. Linden, and P. Thomas (eds.) Financialization in Crisis, Leiden: Brill, (pp. 185-215).

Pettigrew, A.M. (1985). Contextualist research and the study of organizational change processes, in E. Lawler (ed.), Doing Research that is Useful for Theory and Practice, San Francisco, CA: Jossey Bass.

Porter, M.E. (1980). Competitive Strategy, New York: Free Press.

Porter, M.E. (1985). Competitive Advantage, New York: Free Press.

Ranerup, A., Zinner-Henriksen, H. and Hedman, J. (2016). An Analysis of Business Models in Public Service Platforms, Government Information Quarterly 31(1): 6-14.

Rao, H., Morrill, C. and Zald, M.N. (2000). Power Plays: How Social Movements and Collective Action Create New Organizational Forms, in B.M. Staw and R.I. Sutton R.I. (eds.) Research in Organizational Behavior, New York: Elsevier/JAI, pp. 237281.

Sandén, W. (1999). The Net as a Marketplace - the Swedish experience, Teldok Report 123E, KFB - Kommunikationsforskningsberedningen and TELDOK, Stockholm, (pp. 18-27).

Seltsikas, P. and O'Keefe, R.M. (2010). Expectations and Outcomes in Electronic Identity Management: The Role of Trust and Public Value, European Journal of Information Systems 19(1): 93-103.

SOU (2010). E-legitimationsnämnden och Svensk e-legitimation: Betänkande av Utredningen om bildande av en e-legitimationsnämnd, Stockholm: Fritze

Söderström, F. (2012). The National eID in Sweden: An Actor- Network Perspective, in the $\mathrm{PhD}$ Colloquium of the 11th IFIP E-Government Conference, (Kristiansand, Norway).

Van de Ven, A.H. and Poole, M.S. (1995). Explaining Development and Change in Organizations, Academy of Management Review 20(3): 510-540.

VERVA (2008). Slutrapport om säkert elektroniskt informationsutbyte och säker hantering av elektroniska handlingar, Verket för förvaltningsutveckling, Stockholm.

Walsham, G. (1995). Interpretive Case Studies in IS research: Nature and Method, European Journal of Information Systems 4(2): 74-81.

Whitley, E.A. and Hosein, I.R. (2008). Doing the Politics of Technological Decision Making: Due Process and the Debate about Identity Cards in the UK, European Journal of Information Systems 17(6): 668-677.

Wihlborg, E. (2013). Secure eID (electronic identification) in the Intersection of Politics and Technology, International Journal of Electronic Governance, 6(2): 143-151.

Wixom, B.H. and Watson, H.J. (2001). An Empirical Investigation of the Factors Affecting Data Warehousing Success, MIS Quarterly 25(1): 17-41.

Yin, R.K. (1994). Case Study Research: Design and Methods, Newbury Park: Sage Publications.

Zwan, N. van der (2014). Making Sense of Financialization, Socio-Economic Review 12(1): 99-129. 
Table 1. Data sources across cases

\begin{tabular}{|c|c|c|}
\hline Online sources & Documents & Interviews \\
\hline Owners of the Swedish bank- & Andréasson (2011) & 18/04/2013 - Nets - Systems \\
\hline ID https://www.bankid.com & Cuijpers and Schroers (2014) & Architect \\
\hline & Eaton et al. (2014) & 24/06/2013 - BSK - General \\
\hline The Swedish tax authority, & Hansteen et al. (2016) & Manager \\
\hline https://www.skatteverket.se & $\begin{array}{l}\text { Gustafsson and Wihlborg } \\
\text { (2013) }\end{array}$ & $\begin{array}{l}\text { 06/09/2013 - Nets - Systems } \\
\text { Architect }\end{array}$ \\
\hline The Swedish E-identification & Johansson (2004) & 20/09/2013 - BSK - Senior \\
\hline Board (promote and coordinate & Hoff and Hoff (2010) & Consultant \\
\hline electronic identification), & Grönlund (2010) & 18/10/2013 - BSK - General \\
\hline http://www.elegnamnden.se & Sandén (1999) & Manager \\
\hline & Söderström (2012) & 08/11/2013 - Nets - Systems \\
\hline The Federation for Swedish e- & OECD (2016) & Architect \\
\hline identification, & VERVA (2008) & 11/11/2013 - BSK - Senior \\
\hline https://www.sveleg.se & Wihlborg (2013) & Consultant \\
\hline & EU Regulation nr. 910/2014 of & $21 / 11 / 2013$ - BSK - Senior \\
\hline The Swedish Post and & 23 July 2014 & Consultant \\
\hline Telecom Authority, & Danish Ministry of Finance & 22/11/2013 - Nets - Systems \\
\hline & Danish law nr. 417 of 31 May & 10/01/2014 - BankID - Product \\
\hline SPAR, & 2000 & Manager \\
\hline https://www.statenspersonadre & The Swedish Qualified & 20/01/2014 - BankID - Product \\
\hline ssregister.se & Electronic Signatures Act & Manager \\
\hline http://24- & European Directive & 22/01/2014 - SpareBank 1 - \\
\hline timmarsmyndigheten.se & $1999 / 93 / \mathrm{EC}$ & General Manager \\
\hline & SOU (2010) & 24/01/2014 - Nets - Systems \\
\hline The Swedish Bankers & & Architect \\
\hline Association. & & 10/02/2014 - Signicat - \\
\hline http://www.banksakerhet.se/ & & $\begin{array}{l}\text { Business Development } \\
11 / 09 / 2015 \text { - Nets - Business }\end{array}$ \\
\hline Norway BankID: & & Manager \\
\hline https://www.bankid.no/om- & & $12 / 11 / 2015$ \\
\hline oss/presse/ & & $\begin{array}{l}\text { Digitaliseringsstyrelsen - Head } \\
\text { of Division }\end{array}$ \\
\hline Nets Denmark: & & \\
\hline https://www.medarbejdersigna & & \\
\hline tur. $\mathrm{dk} /$ & & \\
\hline http://www.nets.eu/dk- & & \\
\hline da/Om/nyhedsbreve/Pages/def & & \\
\hline ault.aspx & & \\
\hline Digitaliseringsstyrelsen & & \\
\hline Denmark: & & \\
\hline http://www.digst.dk/Service & & \\
\hline menu/Nyheder?page $=0$ & & \\
\hline http://www.digst.dk/Loesninge & & \\
\hline r-og-infrastruktur/NemID & & \\
\hline
\end{tabular}


Table 2. Cross case summary of collective action dimensions over the three phases of e-ID emergence

\begin{tabular}{|c|c|c|c|}
\hline & Phase 1 & Phase 2 & Phase 3 \\
\hline Interests & $\begin{array}{l}\text { Banks (DK, NO) have } \\
\text { convergent interests: } \\
\text { - Economies of } \\
\text { Scale } \\
\text { - Commercial } \\
\text { Revenues } \\
\text { Governments (DK, } \\
\text { NO, SE) have } \\
\text { convergent interests: } \\
\text { - Universal internet } \\
\text { access to } \\
\text { government } \\
\text { services for } \\
\text { citizens } \\
\text { Government and } \\
\text { banks' interests are } \\
\text { separate }\end{array}$ & $\begin{array}{l}\text { Banks and } \\
\text { Government (DK, } \\
\text { NO, SE) have } \\
\text { divergent interests: } \\
\text { - Security Standards } \\
\text { - Ideology }\end{array}$ & $\begin{array}{l}\text { Banks and } \\
\text { Government (DK, } \\
\text { NO, SE) interests } \\
\text { converge: } \\
\text { - Security Standards } \\
\text { - Ideology } \\
\text { - Economic Benefits } \\
\text { - Universal internet } \\
\text { access to } \\
\text { government } \\
\text { services for } \\
\text { citizens }\end{array}$ \\
\hline Resources & $\begin{array}{l}\text { Banks (DK, NO) have } \\
\text { interdependent } \\
\text { resources: } \\
\text { - } \quad \text { Technical } \\
\text { - Organizational } \\
\text { - Installed based } \\
\text { Governments (DK, } \\
\text { NO, SE) have } \\
\text { resources: } \\
\text { - Finance } \\
\text { Banks (DK, NO, SE) } \\
\text { are dependent on } \\
\text { Government resource: } \\
\text { - Civil Registration } \\
\quad \text { Number }\end{array}$ & $\begin{array}{l}\text { Banks and } \\
\text { Government resources } \\
\text { are largely } \\
\text { independent. But } \\
\text { government begins to } \\
\text { see the value of } \\
\text { banks' growing user } \\
\text { base. } \\
\text { Banks (DK, NO, SE) } \\
\text { are dependent on } \\
\text { Government resource: } \\
\text { - Civil Registration } \\
\text { Number }\end{array}$ & $\begin{array}{l}\text { Strong } \\
\text { interdependency of } \\
\text { resources between } \\
\text { Banks and } \\
\text { Government (DK, } \\
\text { NO, SE): } \\
\text { - Installed base } \\
\text { - Infrastructure } \\
\text { - Finance } \\
\text { - Civil Registration } \\
\quad \text { Number }\end{array}$ \\
\hline Governance & $\begin{array}{l}\text { Banks (DK, NO): } \\
\text { - Bankers' } \\
\text { Association } \\
\text { mediate consensus } \\
\text { Government (DK, } \\
\text { NO, SE): } \\
\text { - Government } \\
\text { Agencies } \\
\text { - Law }\end{array}$ & $\begin{array}{l}\text { First attempts at } \\
\text { regulating the } \\
\text { relationship: EU law, } \\
\text { public tender } \\
\text { framework, dedicated } \\
\text { governmental } \\
\text { agencies. } \\
\text { Banks and } \\
\text { Government } \\
\text { governance models } \\
\text { are largely conflicting }\end{array}$ & $\begin{array}{l}\text { Governance is agreed } \\
\text { and put in place: } \\
\text { - DK - Government- } \\
\text { driven } \\
\text { - NO - commercial } \\
\text { agreement } \\
\text { - SE - market- } \\
\text { driven }\end{array}$ \\
\hline
\end{tabular}




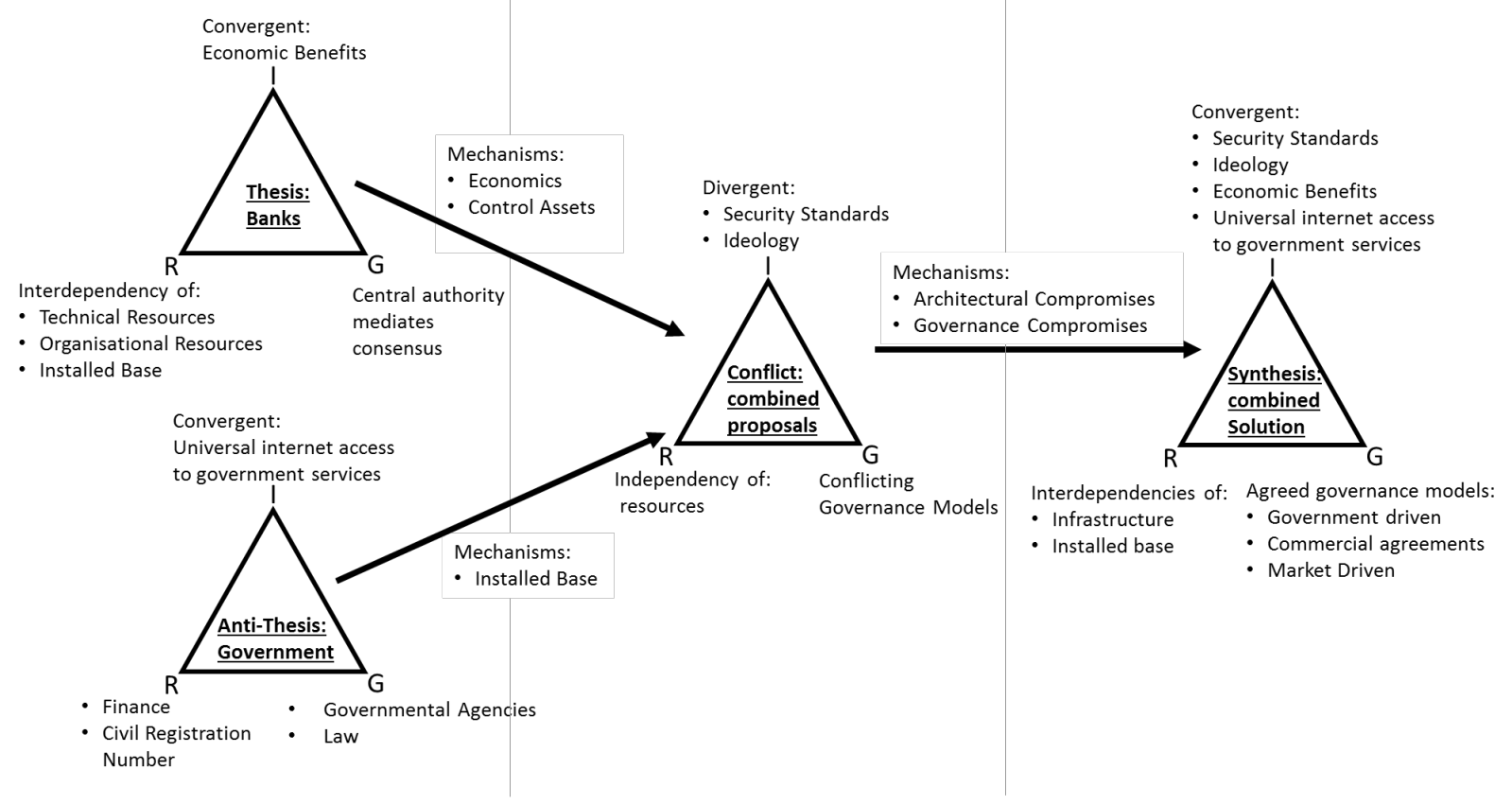

Figure 1. Dialectic process model describing the emergence of national e-ID. 